\title{
PERTAUTAN ADAT DAN SYARA' DALAM DIMENSI SOSIAL DI KOTA GORONTALO
}

\author{
Social Dimension of Sharia and Tradition Bond Gorontalo \\ Oleh : Abd. Kadir. R
}

*Peneliti pada Balai Penelitian dan Pengembangan Agama Makassar

Kantor: Jl. A.P. Pettarani No. 72 Makassar

Email: abdkadirr@,yahoo.co.id

\begin{abstract}
Abstrak
Penelitian ini adalah penelitian sejarah sosial Islam yang dilakukan di Gorontalo. Penelitian ini dilakukan dalam rangka merekonstruksi proses Islamisasi pada kerajaan/kesultanan/daerah lokal di Kawasan Timur Indonesia sebagai bagian integral dari Negara Kesatuan Republik Indonesia. Sejarah dan proses Islamisasi menjadi salah satu pilar penting dalam pembentukan konstruksi sosio-kultural masyarakat indonesia. Dengan mendeskripsikan proses Islamisasi pada ranah sosial-politik serta pengaruh Islam dalam perubahan sosio-kultural diharapkan dapat menjadi refer ensi dalam mengetahui potensi kehidupan sosial masyarakat di Kawasan Timur Indonesia, khususnya di Kota Gorontalo serta akan sangat berguna dalam pembinaan dan pengembangan kehidupan beragama secara umum di Indonesia.

Yang dimaksud Islamisasi dalam penelitian ini merupakan proses yang tak pernah berhenti yang diawali dari penerimaan atau konversi secara massifke dalam Islam baikproses dialog maupun proses integratif hingga proses akulturasi nilai-nilai dan ajaran Islam dengan budaya lokal setempat yang akhirnya membentuk suatu tatanan baru dalam pranata sosio-kultural suatu masyarakat.
\end{abstract}

Kata Kunci: adat, syara', dimensi, sosial

\begin{abstract}
Research is focused on Islamic history in Gorontalo. Research is a part ofproject that aims to reconstruct the Islamization process in east Indonesian region, an integral part of Indonesian Republic. The history and the process of Islamization is the pillar of community social and cultural construction. The result can be used as reference to understand the social and economic potential of east Indonesia region, particularly Gorontalo and to develop public religiosity in Indonesia.

Islamization is a never ending process, from massive converting to Islam, through dialogue and other means, to integrate and acculturate all Islamic values into local community culture, to be manifested in new community order.
\end{abstract}

Key Words: tradition, Sharia, dimension, social

\section{PENDAHULUAN}

\section{Latar Belakang}

$\mathrm{K}$

egiatan penyebaran agama Islam (Islamisasi) merupakan salah satu proses penting dalam proses Islamisasi merupakan bagian terpenting roses Islamisasi merupakan bagian terpenting dan sangat menentukan karena memberikan pengaruh yang sangat signifikan dalam proses sosial pada umumnya daerah di Indonesia. Dengan demikian peran kerajaan lokal dalam proses tersebut tidak bisa serta merta dinafikan, bahkan perlu diangkat kembali ke permukaan demi melacak perananannya dalam integrasi dan kohesi sosial bangsa Indonesia sebagai satu kesatuan yang plural.
Salah satu kerajaan yang cukup menarik diteliti dalam hal ini adalah kerajaan Gorontalo yang telah mengalami proses Islamisasi hingga mempengaruhi nilai, tatanan, dan struktur sosial masyarakatnya. Proses Islamisasi ini hingga pada titik perbaharuan hukum adat dan hukum agama sebagai satu kesatuan. Diktum, "adati hulo-huloka to saraqa, saraqa hulohuloka to Kuraqani" (adat bersendikan syara', syara' bersendikan Alquran). Dengan demikian, Islam telah menjadi bagian penting dan fundamen dalam tatanan sosial kerajaan dan masyarakat Gorontalo. Oleh karena itulah, maka Kementerian Agama, Cq 
Balai Penelitian dan Pengembangan Agama Makassar melakukan penelitian, kajian, dan penulisan tentang Sejarah Sosial Islam pada Kerajaan Gorontalo sebagai wujud kesadaran akan pentingnya persenyawaan keindonesiaan dan keislaman, di samping itu untuk mengangkat kembali sejarah social kerajaan Gorontalo yang selama ini belum ter-cover secara memadai dalam khasanah sejarah nasional Indonesia.

\section{Masalah Penelitian}

Mengacu pada pemaparan terkait dengan kondisi obyektif sejarah lokal dan nasional yang mengalami ketimpangan antara das sein dan das solen sebagaimana yang dideskripsikan di atas, maka penelitian ini akan fokus pada beberapa permasalahan, yaitu:

1. Bagaimana proses Islamisasi pada domain sosialpolitik kerajaan Gorontalo?

2. Bagaimana dampak perubahan sosial politik pasca proses Islamisasi dalam domain kerajaan Gorontalo?

\section{Tujuan Penelitian}

1. Merekonstruksi sejarah kerajaan Gorontalo dengan mengacu pada fakta dan peninggalan sejarah yang ada.

2. Mendeskripsikan proses Islamisasi yang terjadi pada ranah sosial-politik kerajaan Gorontalo.

3. Mendeskripsikan perubahan sosial dan kultural yang terjadi pada pasca proses Islamisasi.

\section{Kegunaan Penelitian}

1. Sebagai bahan informasi awal tentang eksistensi keraj aan Gorontalo untuk dikaj i dan dikembangkan oleh kalangan stakeholder meliputi akademisi, peneliti, sejarawan, dan pemerintah, khususnya pemerintah daerah.

2. Sebagai bahan/referensi bacaan dan riset serta pengungkapan sejarah atas keberadaan kerajaan Gorontalo sebagai salah satu kerajaan Islam yang pernah eksis di Nusantara.

\section{Ruang Lingkup}

1. Deskripsi mengenai eksistensi kerajaan Gorontalo yang meliputi eksplanasi sejarah berdirinya, proses akulturasi dan inkulturasi dengan Islam (Islamisasi), proses peristiwa-peristiwa sejarahnya yang terdiri atas pelaku, struktur, ideologi, serta kultur kerajaan, tatanan sosial-ekonomi kerajaan, interaksi dengan kerajaan-kerajaan lainnya di dalam maupun di luar territorial,
2. Mendeskripsikan perubahan sosial-kultural dan pandangan dunia masyarakat sebagai implikasi yang dipengaruhi oleh Islamisasi.

\section{Perspektif Teoritis dan Tinjauan Pustaka}

\section{Sejarah Sosial}

Penelitian sejarah pada kerajaan Gorontalo ini menggunakan pendekatan sejarah sosial. Secara garis besar, sejarah sosial terbagi atas 2 metode, yaitu sejarah naratif dan sejarah analitis. Sejarah naratif digunakan untuk mengkonstruksi sejarah masa lampau kerajaan, proses terjadinya dari awal hingga akhir dengan memotret peristiwa-peristiwa dan pelaku sejarah yang berperan penting dalam domain sosial dan politik kerajaan. Sedangkan sejarah analitis dengan menggunakan pendekatan multidimensionalmultidisipliner dengan memperhatikan kausalitas alur sejarah, kondisi sosio-kultural, dan kondisi kontekstual, serta komponen-komponen dan kekuatan-kekuatan yang mempengaruhi keberadaannya.

Dalam penulisan sejarah lokal akan mengacu pada model kajian sejarah yang akan memberikan inspirasi yang heuristik yang berguna dalam penelusuran dan pengumpulan data serta penyusunan. Hobsbawn (1972) sangat menekankan penulisan sejarah sosial melalui sebuah model, yang sekalipun sangat tidak formal dan terperinci strukturnya, paling tidak sebagai sebuah kerangka akan tampak lingkaran pusat (central nexas) atau lingkar relasi dari permasalahan yang akan digarap.

Dalam kaitan dengan model sejarah sosial di atas, Kuntowijoyo (1994) mengartikulasikan 6 model, yaitu; 1) model evaluasi, 2) model lingkaran sentral, 3) model interval, 4)model tingkat perkembangan, 5) model jangka panjang-menengah-pendek, 6) model sistematis. Dari 6 model tersebut secarapurposive penelitian ini memanfaatkan model lingkar sentral yang digagas oleh Le Roy Ladurie (1976) yang menulis sejarah bertolak dari titik sejarah di tengah-tengah dan biasanya selalu diawali dengan deskripsi sinkronis (sejarah yang meneliti fenomena-fenomena sosial yang meluas dalam ruang, tetapi terbatas dalam waktu) baru kemudian secara diakronis (sejarah yang meneliti gejala-gejala yang memanjang dalam waktu, tapi terbatas dalam ruang) ditunjukkan pertumbuhannya.

\section{Islamisasi di Indonesia}

"Islamisation is a process which has continued down to the present day", kata MC. Ricklefs sebagaimana yang dikutip oleh Ahmad Sewang, bahwa Islamisasi adalah proses yang tidak pernah berhenti. 
Islamisasi yang berlanjut hingga saat ini dapat diklasifikasi ke dalam beberapa fase sebagaimana yang diungkapkan oleh J. Noordayn (1956). Noordayn membagi fase Islamisasi untuk domain Sulawesi dalam tiga tahap. Pertama, sejak datangnya orang Islam, yaitu datangnya orang-orang Islam untuk pertama kalinya di suatu daerah. Kedua, penerimaan agama Islam, yaitu fase di mana penduduk setempat telah memeluk agama Islam. Ketiga, penyebaran agama Islam, yaitu setelah Islam mulai disebarkan ke dalam masyarakat atau disebarkan ke luar daerah di mana Islam pertama kali diterima.

Islamisasi dapat dipetakan menjadi beberapa domain. Pertama, dengan penerimaan Islam melalui konversi dengan jalan perpindahan agama atau kepercayaan yang dianut sebelum kedatangan Islam, pola penerimaan Islam ini dalam konteks Islamisasi di Sulawesi dalam analisis Sewang. Diawali dari penduduk yang tinggal di pesisir pantai dan berangsur-angsur merambah hingga wilayah pedalaman. Kedua, Islamisasi melalui jalur politik, yaitu tahap pertumbuhan kerajaan/kerajaan Islam di Nusantara. Islamisasi pada tahapan ini tidak lepas dari peran raja yang dielaborasi melalui tesis Uka Tjandrasasmita, bahwajika gubernur atau bangsawan menerima agama baru, rakyat akan siap mengikuti. Hal ini dikarenakan dalam adat mereka, dalam tingkat yang berbeda-beda, raja atau para bangsawan dipandang sebagai wakil Tuhan di muka bumi. Ketiga, pola sosial budaya sebagaimana yang diajukan oleh Ahmad Sewang. Yaitu perubahan yang terjadi secara berfahap dari budaya pra-Islam kepada agama Islam. Para muballigh Islam tidak melakukan perombakan pranata sosial-budaya yang sudah ada, melainkan mereka memberikan nilai-nilai pada pranata lama atau dengan menambahkan pranata baru yang berasal dari budaya Islam.

\section{Metode Penelitian}

\section{Jenis Penelitian}

Penelitian sejarah sosial Islam di Gorontalo dan proses akulturasinya dengan Islam menggunakan metode penelitian sejarah sosial dengan stressing pada sejarah sosial naratif dan analitis.

\section{Teknik Penjaringan Data}

Riset ini menggunakan teknik penjaringan data sejarah secara konvensional berupa kajian kepustakaan dan dipadukan dengan teknik penjaringan data melalui wawancara dan observasi dalam riset sosial dengan konsisten pada penelitian sejarah sosial. Kajian pustaka diposisikan sebagai acuan data primer (utama) dengan mengkaji dan menganalisis sumbersumber tertulis, seperti kronik-kronik dan manuskripmanuskrip klasik, dan literatur-literatur yang muncul kemudian, baik hasil riset sarjana asing maupun domestik.

Dalam upaya melengkapi data-data primer di atas, maka penelitian ini memanfaatkan sumber data sekunder yang terdiri dari dua cara, yaitu; wawancara mendalam (indepth interview) dan observasi. Wawancara mendalam dilakukan dengan cara purposive dengan para informan utama, yaitu orangorang yang dianggap punya banyak pengetahuan mengenai permasalahan sejarah kerajaan di Gorontalo dan proses akulturasinya dengan Islam. Para informan tersebut terdiri atas kalangan bangsawan kerajaan, budayawan, dan sejarawan yang selama ini concern dengan sejarah Islam, tokoh-tokoh pemangku adat di lokasi penelitian, dan lain-lain.

Pemilihan informan sebagai sumber data sekunder yang akan diwawancarai di samping ditentukan dengan cara purposive juga dilakukan dengan cara snowball (bola salju). Yaitu melalui informasi yang diberikan oleh informan yang sudah diwawancarai sebelumnya. Keuntungan yang diperoleh melaui sistem ini adalah peneliti tidak menemui banyak hambatan untuk menentukan informan yang akan diwawancarai berikutnya.

\section{Analisis data}

Data historis yang dikumpulkan baik melalui studi pustaka maupun wawancara dan observasi akan dianalisis melalui beberapa cara, yaitu; rekonstruksi fakta-fakta sejarah tersebut melalui metode; heuristik (tahap pengumpulan dan penyeliaan data), kritik sumber (penilaian dan seleksi), interpretasi dan kodifikasi/penyajian terhadap fakta sejarah kerajaan Gorontalo dan proses akulturasinya dengan Islam.

\section{Asal-Usul Geneologis Kerajaan Gorontalo Pra- Islam}

Sebelum masuknya Islam, di daerah Gorontalo telah terbentuk monarki-monarki yang mengacu pada regulasi hukum adat (adatrecht). Namun sebelum monarkimonarki itu terbentuk, sejarah wilayah Gorontalo pada awalnya terdiri atas masyarakat etnis Gorontalo yang terdiri dari keluarga batih (nuclear family) yang diistilahkan dalam bahasa setempat dengan nama ngalaa. Tiap-tiap ngalaa menghuni sebuah rumah besar yang populer disebut dengan laihe. Yaitu sebuah rumah besar yang disekat dalam beberapa petak. Dari laihe inilah terkonsturksi sistem kepemimpinan yang 
bercorak sosio-kultural. Sebuah laihe dipimpin oleh seorang anggota senior yang kharismatik dan mumpuni dari segi pengalaman dan kearifan hidup. Pemimpin laihe tersebut dinamakanpulo laihe yang artinya orang yang paling utama di laihe\}

Beberapa ngalaa atau laihe ini kemudian membentuk sebuah persekutuan yang disebut dengan linula lipu atau kerajaan yang menghimpun beberapa ngalaa. Linula mempunyai pemimpin internal yang disebut dengan olongia (raja). Otoritas olongia dalam memimpin linula ini tidak didasarkan pada penunjukkan yang dilakukan secara otoriter dan despotik, melainkan melalui konsensus politik di antara kelompok-kelompok laihe yang disebut dengan lemboa. Linula-linula ini yang kemudian akan membentuk federasi yang kemudian membentuk satu kerajaan yang disebut lipu Hulontalo (kerajaan Gorontalo). ${ }^{2}$

Dalam tradisi lisan (oral tradition) masyarakat Gorontalo dikatakan bahwa cikal bakal berdirinya kerajaan Gorontalo dibentuk berdasarkan persekutuan 17 linula yang kemudian berintegrasi ke dalam satu kerajaan dan dengan melalui mekanisme musyawarah maka disepakatilah kerajaan tersebut dipimpin oleh Raja Wadipalapa atau Ilahudu pada tahun 13 85. Ke 17 linula yang mengintegrasikan wilayahnya ke dalam satu kerajaan adalah: 1) Linula Hungginaa dengan olongia adalah Lihawa. 2) Linula Lupoyo dengan olongia adalah Pel. 3) Linula Billinggata dengan olongia Leg. 4) Linula Wuwabu (Uwabu) dengan olongia Wahimolungo. 5) Linula Biawao dengan olongia Wakohuludu. 6) Linula Padengo dengan olongia Palangge. l)Linula Huangobotu dengan olongia Darangi. 8) Linula Tapa dengan olongia Dielohiyodaa.

9) Linula Lawuwono dengan olongia Bunggehulawa. 10) Linula Tuto dengan olongia Titopalangi. 11) Linula Dumanti dengan olongia Buata. 12) Linula Botedia dengan olongia Tanaa. 13) Linula Ptonggo dengan o/cwg/aNgobotu. 14)Linula Panggulo dengan olongia Hungginyalo. 15) Linula Huangobotu dengan olongia Lealini. 16) Linula Tamboo dengan olongia Dailinibotu. 17) Linula Hulontalanggi dengan olongia Wadipalapa (Ilahudu).

Raja Wadipalapa memerintah kerajaan Gorontalo selama lebih kurang 42 tahun (1385-1427). Raja Wadipalapa giat melakukan ekpansi yang disebutkan beliau ditemani oleh Sawerigading dari Luwu untuk menaklukkan negeri-negeri di sekitar teluk Tomini. Pada tahun 1427 raja Wadipalapa digantikan oleh raja Uloli. Pada masa pemerintahan raja Uloli, praktis hanya melanjutkan kebijakan-kebijakanyangtelah dilakukan oleh raja Wadipalapa. Sekitar tahun 1450 terjadi peralihan kekuasaan dari raja Uloli kepada raja Wolanga. Dalam pemerintahan raja Wolanga ini dilakukan sebuah keputusan penting yaitu dengan menjalin hubungan kerjasama dengan kerajaan Limboto (Limutu). Dari hasil perkawinan mereka dikarunai seoranng putra bernama Polamolo. Setelah Polamolo beranjak dewasa, baik raja Wolanga maupun ratu Moliye bersama-sama melakukan ekspansi di sekitar wilayah teluk Tomini. Dengan demikian kekuasaan kerajaan Gorontalo-Limboto diserahkan kepada Polamolo.

Ikatan perkawinan kedua pemimpin kerajaan tersebut makin memperkuat penyatuan kerajaan Gorontalo-Limboto serta semakin memperkuat kekuasaan, kewibawaan, dan militernya. Demi mempertahankan kelangsungan kebesaran kerajaannya, maka pada tahun 1481 keduanya sepakat untuk menobatkan putranyaPolamolo untuk menjadi rajayang memerintah baik di Gorontalo maupun Limboto. Polamolo merupakan raja pertama yang menjadi penguasa pada dua kerajaan sebagai raja ia berjuluk olongia lo balanga yang maksudnya adalah raja yang melak-sanakan pemerintahannya dengan berpindah. Polamolo dalam menjalankan kekuasaannya dengan berpindah, yaitu selama 7 hari di Gorontalo dan 7 hari berikutnya di Limboto.

Dalam rentang masa pemerintahan raja Polamolo terjadi peristiwa yang sangat penting yang disebabkan terjadinya perpecahan politik pada dua kerajaan tersebut. Kewibawaan Polamolo terlalu lemah dan dianggap kurang mampu dalam mengatur dua kerajaan tersebut. Hal ini menyebabkan hubungan GorontaloLimboto menjadi renggang. Meskipun dalam pengambilan keputusan tetap di tangan Polamolo, tapi tetap saja tak mampu meredam perpecahan politik dalam tubuh kerajaan Gorontalo-Limboto. Dan hal ini akhirnya sangat mempengaruhi perjalanan sejarah kedua kerajaan tersebut.

Hubungan kedua kerajaan tersebut akhirnya pecah setelah terbunuhnya raja Polamolo oleh

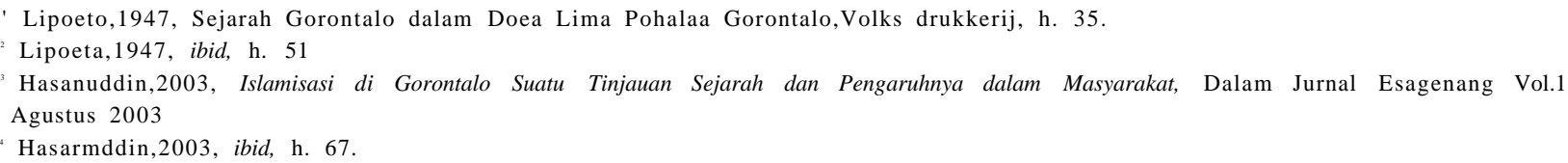


pembesar Limboto. Peristiwa pembunuhan raja Polamolo dipicu oleh ketersinggungan Dumito dan Hungayo dua orang pembesar kerajaan Limboto yang menganggap Polamolo telah menghina kerajaan Limboto dengan menyanjung negeri ayahnya (Gorontalo). Peristiwa ini terjadi sewaktu Polamolo memerintahkan rakyat Limboto untuk membangun sebuah sabaqa di daerah Dehuwalolo (sebuah daerah perbatasan anatara Gorontalo dan Limboto). Selanjutnya kepala Polamolo dikuburkan di Gorontalo dan badannya dikuburkan di Limboto.

Sepeninggal raja Polamolo, kepemimpinan kerajaan Gorontalo dipegang diserahkan pada ratu Ntihedu yang terjadi pada tahun 1490. Selanjutnya tampuk kekuasaan berpindah di tangan raja Detu. Namun pemerintahan raja Detu berlangsung sangat singkat disebabkan kurangnya perhatian raja Detu terhadap urusan pemerintahan. Dalam kepemimpinannya, beljau lebih memilih untuk sibuk pada pekerjaan dan hobinya sebagai pembuat perkakas rumah. Atas kurangnya perhatian dari raja Detu, maka para bate kemudian melakukan musyawarah untuk menentukan kelangsungan pemerintahan kerajaan. Kemudian diputuskan untuk menambah seorang raja dan dipilihlah Pedungge yang merupakan adik dari raja Detu sebagai olongia to huliyliya (raja daerah hilir) sedangkan raja Detu sebagai olongia to tilayo (raja daerah hulu). ${ }^{6}$

Keputusan para bate tersebut membuat terjadinya perombakan besar dalam struktur kerajaan Gorontalo yang sebelumnya hanya dijabat oleh satu orang raja. Selanjutnya, sepeninggal raja Detu dan adiknya raja Pedungge. Pemerintahan kerajaan Gorontalo masih dipimpin oleh sepasang raja, yaitu raja Amai sebagai olongia to tilayo dan raja Tiyabu sebagai olongia to huliyaliya. Pada masa inilah akhirnya, kerajaan Gorontalo hingga berpengaruh pada daerah di sekitarnya memasuki babakan baru yang sangat menentukan kelangsungan kehidupan akibat penerimaan Islam yang pertama kali diterima oleh raja Amai.

\section{Islamisasi Pada Ranah Kerajaan Gorontalo}

Islamisasi kerajaan Gorontalo diawali dengan pengislaman raja Amai yang dimulai dari kunjungannya ke Palasa. Raja Amai kemudian terpikat dan melamar putri Owutango anak raja Palasa, Okomojolo, setelah disepakati oleh pihak kerajaan Palasa, lamaran raja Amai diterima dengan syarat raja Amai masuk Islam beserta seluruh rakyat Gorontalo dan adat istiadat yang berlaku pada masyarakatnya harus didasarkan pada Alquran. Dan persyaratan itu diterima oleh raja Amai, maka dilangsungkanlah pernikahan yang diperkirakan terjadi pada tahun 1524 atau 1495 M. Dari perkawinan keduanya lahir seorang putri yang bernama Matolodulakiki. Setelah proses perkawinan, raja Amai kemudian kembali ke Gorontalo bersama permaisuri didampingi oleh 8 raja-raja kecil di bawah kerajaan Palasa. Ke delapan raja tersebut adalah raja Temalate, Lemboo, Siyendeng, Hulangato, Siduan, Sipayo, Songinti, dan Bunuyo. Keikutsertaan kedelapan rajaraja tersebut bertujuan untuk pengamanan raja Amai beserta permaisurinya selama perjalanan kembali ke Gorontalo serta menjadi pengamanan bagi kesepakatan yang dilakukan oleh raja Amai untuk mengislamkan masyarakat Gorontalo. Mereka juga diharapkan dapat membantu raja Amai dan bertugas membimbing masyarakat Gorontalo untuk masuk Islam serta merancang adat-istiadat Gorontalo yang didasarkan pada ajaran Islam.

Sebenarnya mengenai waktu masuknya Islam di Gorontalo yang diawali dengan keislaman raja Amai terdapat dua perbedaan yang mencolok. Pendapat pertama menyatakan bahwa terjadi pada tahun $931 \mathrm{H}$ yang bertepatan dengan tahun 1524 M. Sedangkan pendapat kedua menyatakan peristiwa tersebut terj adi pada Tahun 899 H.1495 M. Pendapat kedua diperpegangi oleh pihak kerajaan sesuai dengan yang tertulis di pintu gerbang amsuk Mesjid Hunto Sultan Amai yang terletak di kelurahan Biawu kota Gorontalo. Yang didirikan tidak lama setelah raja Amai dan rombongan tiba di Gorontalo. ${ }^{8}$

Sejak saat itu, raja Amai melaksanakan amanah untuk mengislamkan masyarakat Gorontalo dan menjadikan Islam sebagai sendi dari adat istiadat masyarakat Gorontalo. Sejak saat itu, raja Amai diberi gelar to lao pamaklumu dan pada saat itu diberi pula gelar tulutani (sultan), karena beliau sebagai raja Islam pertama di Gorontalo. Secara umum proses Islamisasi di ekrajaan Gorontalo berlangsung secara damai tanpa sedikit pun jalan kekerasan. Rakyat

\footnotetext{
Abdussamad. et. all., 1985. Empat Aspek Adat di Gorontalo, Jakarta, Yayasan 23 Januari 1945, h. 57.

Hasanuddin. 2004, Manado, Balai Kajian Sejarah dan Nilai Tradisional Manado. h. 68.

Ibrahim Polontalo. 1998. Masuk dan Berkembangnya Islam di Gorontalo (Makalah) STIK1P Gororntalo, h. 4.

Sirajuddin Ismail. 2008. Peran Para Sultan dalam Penyebaran Islam di Gorontalo, dalam Jurnal Al Qalam No.XXI, Januari 2008 h. 60.
} 
menerima Islam tanpa ada gesekan yang berarti, rakyat secara sukarela meninggalkan kepercayaan lama yang dinamakan alifuru. Sejak penerimaan Islam, raja dan rakyat Gorontalo tidak lagi melakukan penyembahan. terhadap benda-benda keramat yang dianggap sebagai prototipe Tuhan.' Dan penyebaran islam di Gorontalo bersifat top down artinya karena Islam menyebar akibat peran besar dari penguasa yang selanjutnya diterima secara massif oleh rakyatnya.

Sebagai wujud keseriusannya dalam menjadikan Islam sebagai sendi dari adat-istiadat masyarakat Gorontalo, raja Amai mencetuskan sebuah rumusan yang berbunyi, "syara'a topa-topanga to adati" (Syara' bertumpu pada adat) dalam hal ini Islam telah diadatkan oleh raja Amai. Raja Amai bersama 8 raja yang mendampinginya kemudian berhasil menyusun 185 rancangan adat yang kemudian diberlakukan. ${ }^{10}$

Selanjutnya, sepeninggal raja Amai kemudian digantikan oleh putrinya yaitu ratu Motodulakiki. Selama masa peemrintahannya, ratu Motodulakiki terus mengembangkan proses Islamisasi pada masyarakat Gorontalo dan memperluas sosialisasi Islam di tengahtengah amsyarakat. Walaupun Islam telah menjadi agama resmi di Gorontalo, namun ratu Motodulakiki tetap melakukan pengmbangan pengaruh Islam terhadap adat istiadat dan tata kehidupan masyarakat Gorontalo. Karena pada kenyataannya kebiasaan dari sebagian masyarakat masih belum dapat menyesuaikan dengan syariat Islam. Ratu Motodulakiki kemudian melakukan perubahan adat istiadat dengan memasukkan pengaruh Islam lebih besar dan seimbang dengan adat. Prinsip adat "syara 'a topa-topanga to adatf yang dirumuskan oleh raja Amai dirubah oleh ratu Motodulakiki menjadi "adati hula-hulaa to syara', syara' hula-hulaa to adati" (adat bersendikan syara'dan syara' bersendikan adat). ${ }^{.1}$ Pandangan ratu Motodulakiki ini didasarkan pada prinsip keseimbangan antara posisi hukum adat dan posisi hukum Islam. Kebijakan ratu Motodulakiki ini tetap bertahan, sampai dilakukan perubahan oleh raja Eyato yang berkuasa antara tahun 1673-1679.

Sebelum dinobatkan sebagai raja di Gorontalo, raja Eyato dikenal sebagai seorang khatib besar, seorang sufi yang diketahui sangat mengutamakan kesucian batin. Raja Eyato adalah raja kelima dalam struktur kerajaan Gorontalo Islam setelah raja Amai. Pada masa dua raja antara ratu Motodulakiki dan raja Eyato, proses Islamisasi cenderung statis bahkan dapat dikatakan mundur karena masyarakat cenderung hanya lebih mengutamakan kultur asli amsyarakat Gorontalo dan mengesampingkan kultur yang Islami. ${ }^{12}$ Raja Jogugu Eyato kemudian melakukan pembaharuan dalam kerajaan yang bernuansa syariat Islam, termasuk memperbaharui hukum adat dan agama yang diatur dalam satu kesatuan yang berlaku dalam kerajaan. Sejak raja Eyato inilah dicetuskan prinsip dasar dari kultur kerajaan dan masyarakat Gorontalo, yaitu, "adati hulo-huloqa to saraqa, saraqa hulo-huloqa to kuruqani" (adat bersendi syara', syara' bersendikan Alquran). Akibatnya pada periode ini hukum adat yang berlaku di kerajaan Gorontalo berdasarkan pada .syara' yang sumbernya adalah Alquran. Begitu pula hukum adat yang bertentangan dengan Alquran dinyatakan tidak berlaku lagi di kerajaan. ${ }^{13}$

Akhirnya kerajaan Gorontalo dapat bertahan selama hampir lima abad (1385-1878). Akibat keberhasilan pemerintahan Hindia Belanda menaklukkan berbagai perlawanan dan menguasai kerajaan Gorontalo, maka dikeluarkan surat keputusan kabinet kerajaan oleh pemerintah Hindia Belanda tanggal 26 Mei 1864 dan keputusan Gubarnemen 4 September 1864 no 17. Ketetapan tersebut berisi bahwa raja dan pembesar kerajaan yang berhenti, diberhentikan, atau meninggal dunia tidak dapat digantikan lagi serta tidak dapat membatalkan perjanjian yang telah dilakukan. Setelah raja terakhir yaitu Zainal Abidin Monoarfa yang bergelar ta to kareta hulawa wafat pada tanggal 16 April 1878, maka seluruh pemerintahan kerajaan diambil alih oleh pemerintahan distrik Hindia Belanda yang ada di Gorontalo. Dengan demikian berakhirlah kerajaan Gorontalo dengan raja Zainal Abidin Monoarfa sebagai raja terakhir. ${ }^{14}$ Namun, meskipun kerajaan Gorontalo telah berakhir, Islam sebagai agama dan juga sendi dari kultur masyarakat Gorontalo tetap tak tergantikan. Islam tetap menjadi agama dan sendi adat bagi masyarakat Gorontalo sebagaimaan yang telah dicanangkan oleh raja Eyato.

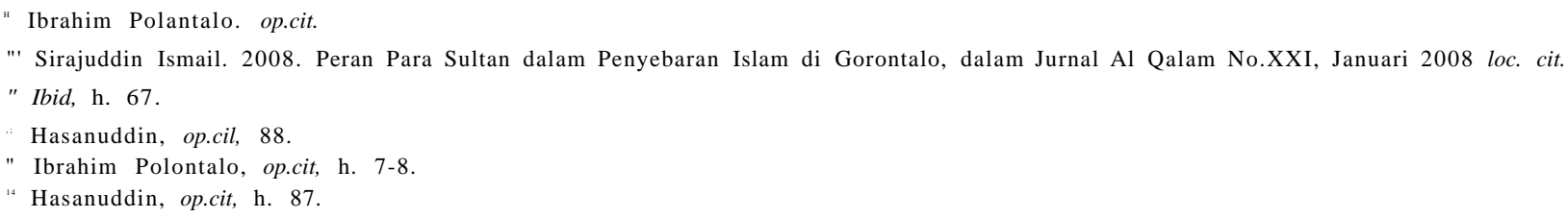




\section{Pengaruh Islam dalam Dinamika Budaya Lokal}

Karena proses Islamisasi di kerajaan Gorontalo bersifat top down, di mana raja memegang peranan yang sangat menentukan dalam proses Islamisasi baik pada ranah keyakinan yang bersifat individual maupun pada ranah kehidupan sosial. Oleh karena itu, berbicara mengenai pengaruh Islam terhadap dinamika budaya lokal yang ada di G'orontalo, sangat tidak bisa dilepaskan dari pengaruh para raja-raja yang pernah berkuasa di kerajaan Gorontalo, di mana mereka berkontribusi sangat besar pada'pengembangan agama Islam dan akulturasinya dengan budaya dan adat-istiadat masyarakat Gorontalo. Di antara beberapa raja Gorontalo yang berkuasa sejak Gorontalo menerima Islam sebagai agama bagi raja dan masyarakatnya.

Dalam sejarah Islamisasi Gorontalo, setidaknya ada tiga raja yang berperan sangat penting dalam proses Islamisasi dan sosialisasi Islam pada masyarakat setempat ke dalam bentuk hukum-hukum adat yang telah diislamisasikan. Ketiga raja tersebut adalah raja Amai, raja Motodulakiki, dan raja Eyato.Masa ketiga raja tersebut juga mencerminkan tiga fase perkembangan Islamisasi di Gorontalo, khususnya pada ranah sosiokultural. Masing-masing dari ketiga raja tersebut memiliki kebijakan danjasayang berbeda dalam proses nagaimana Islam mempengaruhi budaya lokal. ${ }^{15}$ Tahap pertama. adalah tahap penerimaan islam masuk dalam khasanah budaya lokal Gorontalo, yaitu dengan slogan, "Syara' topa-topaga to adati" (syara' ber-sendikan adat), dalam hal ini Islamlah yang kemudian diadatkan dan masuk dalam khasanah budaya masyarakat Gorontalo. Tahap kedua adalah tahap keseimbangan dan merupakan proses akomodasi kultural. Hal ini dilakukan oleh ratu Motodulakiki dengan kebijakannya, "adati hulo-huloqa to syaraqa, syaraqa hulo-huloqa to adati". Pada prinsip ini Islam dan kultur kemudian disejajarkan dan melahirkan prinsip keseimbangan. Sedangkan tahap ketiga adalah tahap penyempurnaan di masa kekuasaan raja Eyato yang melakukan akomodasi kultural. Pada masa raja Eyato dua kebijakan dari raja terdahulu mengenai hukum adat dan hukum syara' disempurnakan oleh raja Eyato yang mendasarkan pada prinsip, "adati hulohuloqa ro saraqa, Saraq hulo-huloa to Hurokani. Tahapan ini adalah tahapan penyempurnaan atas proses Islamisasi yang ada di Gorontalo.
Raja Amai menggunakan pendekatan adaptif dalam memasukkan pengaruh Islam dalam budaya lokal Gorontalo yaitu dengan prinsip "saraqa topa-topangan to adati" (syara' bersendikan adat). Beliau dengan dibantu delapan raja kecil yang men-dampinginya sejak dari palasa merumuskan 185 macam pola adat yang merupakan akulturasi kultur Gorontalo dengan kultur kaum muslimin yang meliputi antara lain adat perkawinan, penyelenggaraan jenazah, pelaksanaan ibadah, mengatur hubungan sesama (adat dalam pergaulan), pembinaan remaja, kesenian yang bernafaskan Islam, kerukunan antara rakyat dan pemerintah, kerukunan hidup, penghormatan terhadap tamu, sosial, pembinaan rumah tangga, dan pembinaan sosial keagamaan. ${ }^{16}$

Raja yang kedua yang juga cukup memberikn pengaruh dalam penetrasi Islam dengan budaya lokal, yaitu ratu Motodulakiki. Di masa pemerintahannya, ratu Motodulakiki membagi dua kategori tokoh masyarakat yaitu tokoh adat dan tokoh agama (ulama atau kadi). Tokoh inilah yang bertugas dalam pengembangan dan pembangunan budaya dan peradaban Islam di Gorontalo. Ratu Motodulakiki melakukan terobosan dengan dalam hal pengembangan kultur Islam di tengah masyarakat. Beliau mengembangkan pola adaptif yang telah dilakukan oleh raja Amai menjadi pola akulturasi dengan diktum adat, "adati hula-hulaqa to saraqa, saraqa hulo-huloqa to adat $F$, (adat bersendi syara', syara' bersendi adat) (Polontalo: 1998). Pola ini akhirnya melahurkan adat yang yang Islami serta syariat islam yang diadatkan. Hingga proses transformasi Islam dalam kehidupan sosio-kultural masyarakat Gorontalo kendati berlangsung secara struktura.1 (top down) namun menggunakan pendekatan dan metode yang bersifat kultural.

Terobosan paling signifikan dalam upaya menjadikan Islam sebagai nilai dan kultur yang mempengaruhi segenap kehidupan masyarakat Gorontalo adalah sebagaimana yang dilakukan oleh raja Eyato. Jika dua pendahulunya menggunakan pendekatan adaptasi (raja Amai) dan akulturasi (ratu Motodulakiki), sedangkan raj a Eyato pure meng-gunakan pendekatan Islamisasi total dengan menjadikan Islam sebagai sendi dari adat. Dengan prinsip "adati hulo-huloqa to saraqa, saraqa hulo-huloqa to kuruqani" (adat bersendi syara', syara 'bersendi kitabullah). Akibatnya dari kebijakan raja Eyato ini, hukum adat yang berlaku di kerajaan didasarkan pada hukum syara' yang

\footnotetext{
Sirajuddin Ismail, op.cit, h. 71.

'Hasanuddin, op.cit, 88.
} 
bersumber pada Alquran. Begitupula hukum adat yang bertentangan dengan Alquran secara otomatis dinyatakan tidak berlaku di kerajaan.

Berdasarkan pada prinsip adat tersebut, raja Eyato kemudian menerapkannya pada kebijakan-kebijakan praktis di antaranya:

1. Menambahkan kalimat dalam ikrar penobatan raj a yang sebelumnya adalah:

a. Huta-huta lo ito eya (tanah, adalah tanah kepunyaan tuanku)

b. Taluhu-taluhu lo ito eya (air, adalah air kepunyaan tuanku)

c. Duputo-duputo lo ito eya (angin, adalah angin kepunyaan tuanku)

d. Tawu-tawu lo ito eya (manusia, adalah manusia kepunyaan tuanku). ${ }^{17}$

Pada masa penobatannya, raja Eyato menam-bahkan kalimat "dilo paluliya lo ito eya" (tetapi tuanku tidak diperbolehkan menyalahgunakannya), Penambahan kalimat ini sangat sesuai dengan ajaran islam di mana tidak ada kekuasaan mutlak pada diri sultan atau raja. Pada upacara penobatannya, raja Eyato juga menambahkan kalimat yang penuh makna menyangkut tugas raja yang sangat berat dan mulia, antara lain:

a. Tugas maharaja adalah "moiyo to Allah ... wolo mursala loowali oe sagala" (membantu Allah dan Nabi utusanNya yang telah menciptakan segala-galanya.

b. Usaha memakmurkan rakyat berpedoman pada, "agama to taluиjipu pei haluluu" (agama menjadi patokanku dalam mengendalikan negeri ini)

c. Penyelenggaraan pemerintahan didasarkan pda, "olide olimbunga oledia poheluma" (ada aturan pemerintahan yang didampingi oleh dewan permusyawaratan.

2. Pembinaan Islam. Sistem pemerintahan raja Eyato mempertahankan ketiga sistem pemerintahan. Salah satu diantaranya adalah menempatkan qadi pada bagian formal. Tugas qadi adalah pem-binaan Islam, penasehat raja, mengetuai pengadilan pidana dan perdata. Di samping itu, tugas qadi adalah membina Islam, membangun mesj id dengan wakaf, melaksanakan penyeleng-garaan perayaan Islam baik di istana maupun di mesj id, membina peradilan, menjadi penasehat dalam sidang kerajaan, dan peradilan dalam hukum Islam. Sedangkan dalam tugasnya, qadi dibantu oleh; mapuli atau mufti (penasehat bidang agama Islam), panthongo (penasehat bidang ilmu falak yang bertugas menetapkan waktu shalat dan masuknya bulan hijriyah), imam (pemimpin ibadah), saradaa fwakil imam/pengatur tata tertib peribadatan), lebi (pembantu saradaa), dan kasisi (anggota pembantu saradaa).

Pada masyarakat Gorontalo. Islam telah menjadi bagian dari adat yang tak terpisahkan, atau bahkan lebih dari itu Islam telah menjadi pewarna yang memberi corak pada berbagai bentuk-bentuk praktek adat masyarakat Gorontalo, karena Islam merupakan identitas yang tak terpisahkan dari masyarakat Gorontalo. Hingga yang terjadi selain Islamisasi kultur Gorontalo, juga pada kulturisasi Islam yang kemudian menjadi bagian vital dalam tata kehidupan masyarakat Gorontalo. Adapun pengaruh ajaran Islam (syara') yang mewarnai budaya lokal Gorontalo hingga terejawantahkan dalam bentuk praktek-praktek ritual adat yang mencakup berbagai asek kehidupan masyarakat seperti proses perkawinan, penyelenggaraan kematian, pelaksanaan ibadah, hubungan sosial, pembinaan anak remaja, kesenian, hubungan kerajaan dengan rakyat, pembinaan kehidupan masyarakat, penghormatan terhadap tamu, hubungan sosialkeagamaan, dan pembinaan hubungan rumah tangga, dan lain-lain.

\section{PENUTUP}

\section{Kesimpulan}

Proses Islamisasi di Gorontalo berlangsung secara top down yang diawali dengan masuk Islamnya raja yang kemudian diikuti oleh segenap rakyatnya secara sukarela. Tahapan Islamisasi di Gorontalo sendiri melalui tiga fase yaitu fase adaptasi yang dimulai sejak masuk Islamnya raja Amai dan segenap rakyatnya. Yaitu dengan menjadikan syara' bersendikan adat. Tahap kedua adalah pada masa pemerintahan ratu Motodulakiki yang menggunakan metode akulturasi dengan memposisikan adat dan syara' secara seimbang. Tahap puncak dari Islamisasi kerajaan Gorontalo adalah pada masa raja Eyato dengan menjadikan syara' sebagai sendi bagi adat bertumpu yang didasarkan pada kitabullah.

'J.Hasanuddin,2004, Gorontalo, tantangan dan Kebijakan Soial Politik Ekonomi Kolonial Belanda, Menado, Balai kajian Sejarah dan Nilai Tradisional Menado, ibid. 
Akhirnya Islam pun menjadi bagian yang tak terpisahkan dari identitas orang Gorontalo, baik sebagai individu maupun kolektif. Bukan orang Gorontalo kalau tidak beragama Islam, seperti itulah yang menjadi istilah masyarakat Gorontalo yang menandakan bahwa orang Gorontalo pastilah beragama Islam. Dalam kehidupan bermasyarakat pun Islam diposisikan sebagai pemberi corak dan warna bagi serangkaian adat-istiadat masyarakat Gorontalo. Sehingga dapat dikatakan Islamisasi pada kerajaan Gorontalo terus bertahan hingga kini dan ini terlihat dengan serangkaian adat istiadat dan budaya masyarakat Gorontalo yang sangat kental dengan nuansa Islam. Demikian pula aspek normatif dari syariat Islam pun diinstitusionallisasi dalam perangkat dan aturan adat Gorontalo hingga kini.

\section{Rekomendasi}

1. Salah satu kendala dalam pelacakan sejarah Gorontalo adalah tidak adanya pusat informasi yangmemadai mengenai sejarah dan kebudayaan Gorontalo. Oleh karena itu, perlu kiranya dibuat sebuah pusat informasi sejarah dan kebudayaan
Gorontalo yang representatif berupa museum yang menyimpan berbagai sumber dan peninggalan sejarah Gorontalo.

2. Banyak situs dan peninggalan sejarah, khususnya yang berkenaan dengan sejarah Islam di Gorontalo yang masih belum terlacak, oleh karena itu, perlu kiranya dilakukan upaya serius dalam rangka pelacakan situs dan peninggalan sejarah yang sangat berkaitan dengan sejarah Islam di Gorontalo sebagai bagian dari upaya untuk merekonstruksi sejarah Islam di Gorontalo.'

3. Tradisi dan kebudayaan masyarakat Gorontalo yang memuat pesan-pesan kearifan lokal yang bernafaskan Islam sangat perlu untuk selalu dilestarikan karena menjadi bagian dari keragaman corak kultur Islam yang ada di Indonesia.

4. Perlu diadakan penelitian lanjutan yang berkenaan dengan sejarah sosial Islam di Gorontalo dalam rangka lebih merekonstruksi sejarah sosial Islam yang ada di Gorontalo. 


\section{DAFTAR PUSTAKA}

Abdullah, Taufik. Sejarah Lokal di Indonesia. Yogyakarta: UGM Press. 1990.

Abdussamad, et, al. EmpatAspekAdat Gorontalo. Jakarta: Yayasan 23 Januari 1942. 1985.

Hasanuddin. Islamisasi di Gorontalo: Suatu Tinjauan Sejarah dan Pengaruhnya dalam Masyarakat. Dalam Jurnal Esagenang. Vol I, No. 2. Agustus 2003.

, Gorontalo: Tantangan dan Kebijakan Sosial, Politik, Ekonomi Kolonial Belanda. Manado. Balai Kajfan Sejarah dan Nilai Tradisional Manado bekerjasama dengan Pemerintah Provinsi Gorontalo. 2004.

Ismail, Sirajuddin. Peran Para Sultan dalam Penyebaran islam di Gorontalo. Dalam Jurnal al-Qalam. No Xxi. Januari 2008.
Kuntowijoyo. Penjelasan Sejarah. Yogyakarta: Tiara Wacana. 2008. , MetodologiSejarah. Yogyakarta: Tiara Wacana. 2008.

Lipoeto, Sedjarah Gorontalo dalam Doea Lima Pohalaa. Gorontalo: VolksDrukkerij. 1947.

Lahaji, Pemetaan Kerukunan dan Kerawanan Sosial di Kota Gorontalo. Makalah. 2007.

Maili, Mashadi. Corak Mistisisme dalam Tradisi Upacara $<$, Keagamaan: Studi Antropologis Terhadap Fenomena Keislaman di Kota Gorontalo. Makalah. 2009.

Polontalo, Ibrahim. Masuk dan Berkembangnya Islam di Gorontalo. Makalah. STKIP Gorontalo. 1998.

Tohopf, Ridwan, Penelusuran Sejarah Pendidikan Tinggi Agama di Gorontalo, (Laporan Penelitian) Gorontalo, IAIN Sultan Amai. 2005. 